Indonesian Journal of Biotechnology, December, 2014

Vol. 19, No. 2, pp.176-183

\title{
Polymorphism of Transcription Factor 7-Like 2 Gene and HOMA- $\beta$ Level of Individuals With and Without Type 2 Diabetes Mellitus Family History
}

\author{
Waode Astria Sahrani ${ }^{1 *}$, Indwiani Astuti ${ }^{2}$, Ahmad Hamim Sadewa ${ }^{3}$
}

\footnotetext{
${ }^{1}$ Master Program of Basic Medical Science and Biomedic, Molecular Medicine Department, Faculty of Medicine, Universitas Gadjah Mada, Yogyakarta, Indonesia.

${ }^{2}$ Department of Pharmacology, Faculty of Medicine, Universitas Gadjah Mada, Yogyakarta, Indonesia.

${ }^{3}$ Department of Biochemistry, Faculty of Medicine, Universitas Gadjah Mada, Yogyakarta, Indonesia.
}

\begin{abstract}
Family history has considered as a risk factor of type 2 diabetes. Transcription factor-7 like 2 (TCF7L2) has role to regulates insulin secretion and blood glucose homeostasis. The aim of current study was to determine the rs7903146 polymorphism of TCF7L2 gene and homeostatic model assessment- $\beta$ (HOMA- $\beta$ ) level on individual with and without type 2 Diabetes Mellitus (DM) family history. This work is a case-control study. Thirty six subjects with type 2 DM family history and 36 subjects without type 2 DM family history were recruited. HOMA- $\beta$ measure to analyze the insulin secretion. Polymorphisms of TCF7L2 gene was analyzed by using PCR-RFLP method. Statistical analysis was performed by using T-test, Mann-Whitney and Chi-square with significance level 0.05 . The frequency of the T allele of the cases were $4.2 \%$ and the controls were $2.8 \%(p=0.500)$. The odd ratio was 0.649 (CI;95\%:0.106-4.055). The HOMA- $\beta$ levels of the cases were significant low (132.56 \pm 62.48$)$ compared with the controls $(266.09 \pm 1.68)$ with $p=0.000$. The subjects with type 2 DM family history have a similar frequency of having T alleles and CT/TT genotypes. The subjects with type 2 DM family history has significantly lower HOMA- $\beta$ levels than subject without DM family history.
\end{abstract}

Keyword: Type 2 DM family history, TCF7L2 gene, rs7903146 polymorphism, HOMA- $\beta$

\section{Introduction}

Diabetes mellitus (DM) is a multifactorial disease which has a complex interaction between genetic and environment factors. Genetic factor is an important role to determine the incidence of familial diabetes (Bener et al., 2013). Erasmus et al. (2001) has reported that the incidence of type 2 diabetic was contributed by genetic role and family aggregation in some population.

Family history is considered as a risk factor in type 2 DM (Bener et al., 2013).

\section{"Corresponding author:}

Waode Astria Sahrani

Master Program of Basic Medical Science and Biomedic, Molecular Medicine Department, Faculty of Medicine, Universitas Gadjah Mada, Yogyakarta, Indonesia
Harrison et al. (2003) has shown that diagnosis of DM will be increase 2-4 fold if one or both parents was suffering from diabetes mellitus.

The Transcription Factor 7-like 2 (TCF7L2) is a gene which contributed in the developing of type $2 \mathrm{DM}$. The TCF7L2 gene has played a role to encoding the transcription factor which involved in Wingless-type mouse mammary tumor virus (MMTV) integration site family member (Wnt) of signal pathway (Lyssenko et al., 2007). The Wnt signal has an important action to regulate several genes through TCF7L2 activation, such as the expression of proglucagon gene which encoding the insulintropic hormone, glucagon-like peptide-1 (GLP-1). The TCF7L2 activates pro-glucagon 
gene expression lead to GLP-1 secretion (Tong et al., 2009). The glucagon-like peptide-1 has played a role in blood glucose homeostasis and elevates insulin secretion, so this could be explained that TCF7L2 has an indirect role as a regulation factor of insulin secretion and blood glucose homeostasis (Tong et al., 2009; Yu et al., 2009).

The rs7903146 (IVS3C/T) polymorphism contributed $10-25 \%$ in all of diabetes cases (Xavier et al., 2009). The rs7903146 polymorphism of TCF7L2 gene has been related with type 2 diabetes which lead to impaired insulin secretion and elevated hepatic glucose production (Wegner et al., 2008).

A number of studies have demonstrated that individuals with type 2 DM family history has 2-fold risk to suffering from type $2 \mathrm{DM}$ than individuals without type 2 DM family history (Wicaksono, 2011). The genetic polymorphism of individuals with type $2 \mathrm{DM}$ family history is interested to be investigated in Indonesian population. The aim of this study was to investigate the rs7903146 polymorphism of TCF7L2 gene among individuals with and without type 2 DM family history in Indonesian population.

\section{Materials and Methods}

This study is a case-control study. The subject was divided into case and control groups. The case group consist of patient with type $2 \mathrm{DM}$ family history was recruited from outpatients clinic of Dr. Sardjito Hospital Yogyakarta. The control group is subjects without type 2 DM family history which was recruited from community in Yogyakarta. This study has been approyed by Medical and Health Research Ethics Committee, Faculty of Medicine, UGM.

Inclusion criteria of this study were healthy subjects, male or female at age 19-39 years old, BMI $\leq 24 \mathrm{~kg} / \mathrm{m}^{2}$ and signing the informed consent form.

\section{Blood chemical examination}

Whole blood samples which obtained from the subjects after informed consent has been done. Glucose oxidase-p-amino phenazone (GOD-PAP) method was used for measuring blood glucose line. Insulin level was analyzed from blood serum by ELISA method (DRG ${ }^{\circledR}$ kit) to obtain the HOMA- $\beta$ level. The HOMA- $\beta$ was calculated to determine the function of pancreatic beta cell with the following below (Chen et al., 2012; Oya et al., 2014):

\section{DNA isolation}

DNA was isolated using Wizard ${ }^{\circledR}$ Genomic DNA Purification Kit (Promega). DNA was isolated from $400 \mu \mathrm{L}$ leucocytes sample and was briefly performed by mixed the $900 \mu \mathrm{L}$ erythrocyte lyses buffer, 300 $\mu \mathrm{L}$ nucleid lyses solution, $100 \mu \mathrm{L}$ protein precipitation solution, $300 \mu \mathrm{L}$ isopropanol, $300 \mu \mathrm{L}$ ethanol $70 \%, 100 \mu \mathrm{L}$ DNA rehydration solution and incubate for 12 hour at $4^{\circ} \mathrm{C}$.

\section{Polymerase chain reaction (PCR)}

Amplification of DNA was performed by mixed the $15 \mu \mathrm{L}$ PCR mix, $11 \mu \mathrm{L} \mathrm{H}_{2} \mathrm{O}, 2 \mu \mathrm{L}$ DNA in a tube, then spin down for a minute at $3500 \mathrm{rpm}$. The primers (IDT, Inc) sequence for TCF7L2 gene segment amplification were 5' - GAG AGC TAA GCA CTT TTT AGG TA - 3' (forward) and 5' - CTG ACA TTG ACT AAG TTA CTT GC - 3' (reverse). PCR amplification conditions were as follows: an initial denaturation at $95^{\circ} \mathrm{C}$ for 15 minutes, followed by 35 cycles of denaturation at $95^{\circ} \mathrm{C}$ for 30 seconds, annealing at $54^{\circ} \mathrm{C}$ for 30 seconds, extension at $72^{\circ} \mathrm{C}$ for 30 seconds, final extension at $72^{\circ} \mathrm{C}$ for 5 minutes and cooling at $4^{\circ} \mathrm{C}$. The PCR program was running for $1 \mathrm{~h} 36$ minutes.

\section{Restriction fragment length polymorphism (RFLP)}

The enzymatic digestion of PCR product was performed by mixed the $0.5 \mu \mathrm{L}$ restriction enzyme Rsa1, $4.5 \mu \mathrm{L} \mathrm{H}_{2} \mathrm{O}, 1 \mu \mathrm{L}$ tango buffer, 4 $\mu \mathrm{L}$ DNA in a tube. The reaction mixture was 
incubated for 16 hour at $37^{\circ} \mathrm{C}$. The $\mathrm{C}$ allele was represented by two fragments of 91 and 22 base pairs and T allele was represented by one fragment of 113 base pair.

\section{Electrophoresis}

Electrophoresis analysis was performed by using the $3 \%$ of agarose with ethidium bromide (EtBr).

\section{Statistical analysis}

Statistical analysis was performed by using univariate (mean, SD) and bivariate (independent t-test, Mann-Whitney and Chisquare) analysis.

\section{Results}

\section{Subject Characteristic}

We enrolled 72 subjects that consisted of 36 individual with type 2 DM family history and 36 individual without type 2 DM family history. The age, body mass index (BMI), blood pressure (systolic blood pressure and diastolic blood pressure), and fasting blood glucose were not statistically difference between subjects with and without type 2 DM family history (Table 1).

\section{The rs7903146 polymorphism of TCF7L2 gene}

The result of genotype analysis of rs7903146 polymorphism of TCF7L2 gene in this study was shown on Figure 1.

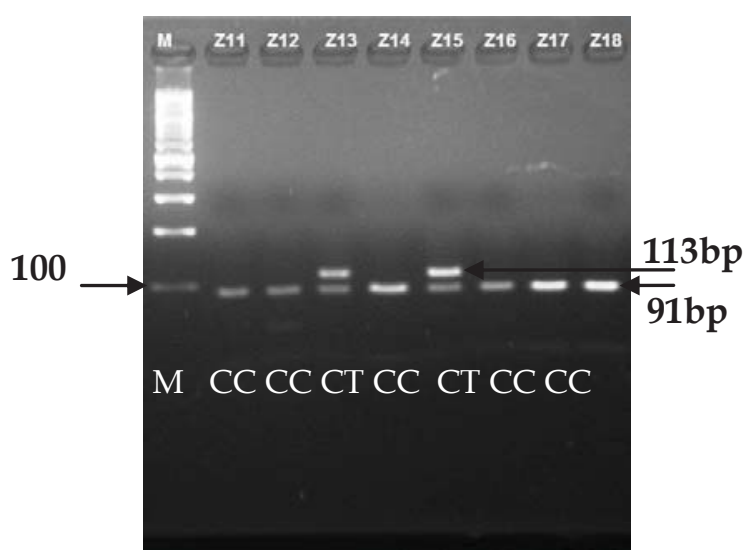

Figure 1. The genotyping result of rs7903146 polymorphism of TCF7L2 gene. $\mathrm{M}=$ Marker. CC genotype $=$ wild-type $(91 \mathrm{bp}$ and $22 \mathrm{bp}), \mathrm{CT}$ genotype $=$ variant $(113 \mathrm{bp}$ and $91 \mathrm{bp})$.

The frequency distribution of genotypes and alleles of rs7903146 polymorphism of TCF7L2 gene

The genotype and allele distribution of rs7903146 polymorphism of TCF7L2 gene is shown in Table 2 . The odds ratio (OR) and Hardy-Weinberg is also shown in Table 2.

Data are presented as mean \pm SD. Distribution of data was analyzed by Shapiro-Wilk: $p \geq 0.05$. Independent $t$-test: $p \leq 0.05$ : significantly difference. *MannWhitney U test: pć 0.05:significantly difference.

Table 1. Characteristic of subjects with and without type 2 DM family history

\begin{tabular}{|c|c|c|c|}
\hline Variable & $\begin{array}{c}\text { With type } 2 \text { DM family } \\
\text { history } n=36\end{array}$ & $\begin{array}{l}\text { Without type } 2 \text { DM } \\
\text { family history } n=36\end{array}$ & $\begin{array}{c}p \\
(\mathrm{CI} 95 \%)\end{array}$ \\
\hline Gender (M/F) & $9 / 27$ & $9 / 27$ & $\begin{array}{c}1,00 \\
(0,34-2,90)\end{array}$ \\
\hline Age (year) & $23,64 \pm 3,66$ & $24,19 \pm 3,50$ & $\begin{array}{c}0,37^{*} \\
0,90\end{array}$ \\
\hline BMI $\left(\mathrm{kg} / \mathrm{m}^{2}\right)$ & $20,45 \pm 2,15$ & $20,51 \pm 1,87$ & $(-1,01-0,89)$ \\
\hline \multicolumn{4}{|l|}{ Blood pressure (mmHg) } \\
\hline Sistole & $109,50 \pm 9,44$ & $109,33 \pm 8,24$ & $\begin{array}{c}0,93 \\
(-4,00-4,33)\end{array}$ \\
\hline Diastole & $72,08 \pm 7,18$ & $73,17 \pm 7,93$ & $\begin{array}{c}0,54 \\
(-4,64-2,47)\end{array}$ \\
\hline Fasting Blood Glucose (mg/dL) & $90,64 \pm 12,55$ & $89,61 \pm 9,87$ & $\begin{array}{c}0,70 \\
(-4,28-6,33)\end{array}$ \\
\hline
\end{tabular}


Sahrani et al.

I.J. Biotech.

Table 2. The distribution of genotype (TT, CT, and CC) and allele (T and C) of TCF7L2 gene among subjects with and without type $2 \mathrm{DM}$ family history

\begin{tabular}{|c|c|c|c|c|c|c|}
\hline \multicolumn{2}{|c|}{ Variable } & $\begin{array}{c}\text { With type } 2 \\
\text { DM family history } \\
n=36\end{array}$ & $\begin{array}{l}\text { Without type } 2 \mathrm{DM} \\
\text { family history } \\
\mathrm{n}=36\end{array}$ & OR & $p$ & H-W \\
\hline Genotype & $\begin{array}{l}\text { CC } \\
\text { CT } \\
\text { TT }\end{array}$ & $\begin{array}{c}33(91.7 \%) \\
3(8.3 \%) \\
0(0 \%)\end{array}$ & $\begin{array}{c}34(94.4 \%) \\
2(5.6 \%) \\
0(0 \%)\end{array}$ & 0.647 & 0.500 & 1.000 \\
\hline Allele & $\begin{array}{l}\mathrm{C} \\
\mathrm{T}\end{array}$ & $\begin{array}{c}69(95.8 \%) \\
3(4.2 \%)\end{array}$ & $\begin{array}{c}70(97.2 \%) \\
2(2.8 \%)\end{array}$ & 0.657 & 0.500 & \\
\hline
\end{tabular}

The Pearson Chi-square-Fishers Exact Test: $p<0,05$ : significantly difference. H-W= Hardy-Weinberg Equilibrium.

Table 3. The difference means of insulin and HOMA- $\beta$ levels between subject with and without family history of type $2 \mathrm{DM}$

\begin{tabular}{cccc}
\hline Variable & $\begin{array}{c}\text { With family history } \\
\mathbf{D M}\end{array}$ & $\begin{array}{c}\text { Without family } \\
\text { history DM } \\
\mathbf{n}=\mathbf{3 6}\end{array}$ & $\boldsymbol{p}$ \\
& $\mathbf{n}=\mathbf{3 6}$ & $16.18 \pm 3.76$ & 0.00 \\
Insulin $(\mu \mathrm{IU} / \mathrm{mL})$ & $9.77 \pm 6.35$ & $266.09 \pm 1.68$ & 0.00 \\
HOMA- $\boldsymbol{\beta}(\%)$ & $132.56 \pm 62.48$ & 0 \\
\hline
\end{tabular}

Data are expressed as mean \pm SD. Independent T-test: $p \leq 0,05 .{ }^{*}$ Mann-Whitney U test: $p \leq 0,05$.

Table 4. The difference means of insulin level on CT and TT genotypes among subject with and without type 2 DM family history

\begin{tabular}{|c|c|c|c|c|c|c|}
\hline \multirow[t]{2}{*}{ Variable } & \multicolumn{2}{|c|}{$\begin{array}{l}\text { With type } 2 \text { DM } \\
\text { family history }\end{array}$} & \multirow[t]{2}{*}{$P$} & \multicolumn{2}{|c|}{$\begin{array}{l}\text { Without type } 2 \text { DM } \\
\text { family history }\end{array}$} & \multirow[t]{2}{*}{$p$} \\
\hline & $\begin{array}{c}C C \\
(n=33)\end{array}$ & $\begin{array}{c}\text { CT } \\
(n=3)\end{array}$ & & $\begin{array}{c}C C \\
(n=34)\end{array}$ & $\begin{array}{c}\text { CT } \\
(n=2)\end{array}$ & \\
\hline $\begin{array}{c}\text { Insulin level } \\
(\mu \mathrm{IU} / \mathrm{mL})\end{array}$ & $9.1 \pm 5.3$ & $16.8 \pm 12.9$ & $0.40^{*}$ & $16.2 \pm 3,8$ & $14.6 \pm 0,7$ & 0.54 \\
\hline
\end{tabular}

Data are described as mean \pm SD. Independent T-test: $p \leq 0,05$. *Mann-Whitney U test: $p \leq 0,05$.

Table 5. The difference means of HOMA- $\beta$ on CC and CT genotypes among subjects with and without type 2 diabetes family history

\begin{tabular}{|c|c|c|c|c|c|c|}
\hline \multirow[t]{2}{*}{ Variable } & \multicolumn{2}{|c|}{$\begin{array}{l}\text { With type } 2 \mathrm{DM} \\
\text { family history }\end{array}$} & \multirow[t]{2}{*}{$p$} & \multicolumn{2}{|c|}{$\begin{array}{l}\text { Without type } 2 \text { DM family } \\
\text { history }\end{array}$} & \multirow[t]{2}{*}{$p$} \\
\hline & $\begin{array}{c}C C \\
(n=33)\end{array}$ & $\begin{array}{c}\text { CT } \\
(n=3)\end{array}$ & & $\begin{array}{c}\text { CC } \\
(n=34)\end{array}$ & $\begin{array}{c}\mathrm{CT} \\
(\mathrm{n}=2)\end{array}$ & \\
\hline HOMA- $\beta(\%)$ & $130.5 \pm 59.6$ & $154.3 \pm 1.03$ & 0.53 & $244.9 \pm 1.12$ & $626.1 \pm 5.51$ & 0.30 \\
\hline
\end{tabular}

Data are presented as mean \pm SD. Mann-Whitney U test: $p \leq 0,05$.

The difference mean of Insulin and HOMA- $\beta$ levels

The mean of insulin and HOMA- $\beta$ levels of subjects with type 2 DM family history was significantly lower than subjects without type 2 DM family history $(p=0.00)$ (Table 3).
The association of $C C$ and $C T$ genotypes of TCF7L2 gene with insulin and HOMA- $\beta$ levels

Statistically, the mean of insulin and HOMA- $\beta$ levels in CC and CT genotypes was not significantly different between two groups (Table 4 and 5). 


\section{Discussion}

Family history is important in the clinical setting and patient's management, such as modification of environmental factors or lifestyle, increasing diagnosis accuracy, and prevention of expensive medical expenses (Das et al., 2012). A type 2 DM family history may be associated with insulin resistance and dysfunction of pancreatic $\beta$-cells (Arslanian et al., 2005). Danadian et al. (1999) showed that individuals with type 2 DM family history leads to decrease the insulin sensitivity by $25 \%$.

Rs7903146 polymorphism of TCF7L2 gene plays a role in the pathogenesis of type $2 \mathrm{DM}$ which affects the regulation of transcription in insulinothropic GLP-1 hormone thereby reducing the secretion of insulin and improve glucose hepatic production. Single nucleotide polymorphism (SNP) rs7903146 in intron 3 is a $\mathrm{C}$ allele transformation into $\mathrm{T}$ allele. The $\mathrm{T}$ allele in TCF7L2 gene associated with insulin secretion interference and insulin sensitivity enhancement (Alibegovic et al., 2010). Lyssenko et al. (2007) observed that the CT/ TT genotype was strongly associated with type $2 \mathrm{DM}$. The $\mathrm{T}$ allele is also associated with insulin secretion interference, increasing glucose production. In addition, $\mathrm{T}$ allele has a larger role in open chromatin and activity enhancement compared to C allele (Gaulton et al., 2010). The dysfunction of beta cells is caused by protein TCF7L2 deficiency and post-trancription TCF7L2 disorders. The basic mechanism that explains the regulation of transcription and translation of TCF7L2 was still unclear (Shu et al., 2009). The depletion of TCF7L2 caused a five-fold increase in $\beta$-cell apoptosis, a two-fold decline in $\beta$-cell proliferation and a two-fold decrease in insulin secretion (Shu et al. (2008).

The subjects enrolled in this study were in normal condition. All subjects blood glucose level was $\leq 126 \mathrm{mg} / \mathrm{dL}$, mean of level of body mass index (BMI) of two groups were $20 \mathrm{~kg} / \mathrm{m}^{2}$, and subjects blood pressure was $\leq 140 / 90 \mathrm{mmHg}$. This result was associated with subject characteristic which healthy subject. The PERKENI was reported that diagnose of diabetes was established if fasting blood glucose level $\geq 126 \mathrm{mg} / \mathrm{dL}$ $(7.0 \mathrm{mmol} / \mathrm{L})$, not obesity $\left(\leq 25 \mathrm{~kg} / \mathrm{m}^{2}\right)$ and normal blood pressure $(\leq 140 / 90 \mathrm{mmHg})$ (PERKENI, 2011; Annurad et al., 2003).

This study found only two genotypes in each group, there are wild type homozygote genotype (CC) and variant heterozygote genotype (CT). This result was different with previous study that found TT, TC, and CC genotypes at Japanese (Miyake et al., 2007), Indian population (Jyothi et al., 2013), Chinese population (Wang et al., 2013) and Brazilian population (Marquizine et al., 2008).

The frequency distribution of $\mathrm{CC}$ genotype was higher than CT genotype. However, it was not statistically different between subjects with and without type $2 \mathrm{DM}$ family history ( $p=0.500)$. Alsmadi et al. (2008) reported that the frequency of genotype and allele of rs7903146 polymorphism at Arab population was not statistically different between case and control subjects $(p=0.573$ and $p=0.675)$, respectively. This result was different with previous study at Dutch Breda population. Vliet et al. (2007) reported that there was significantly different $(p=0.009$ and $p=0.00004$, respectively). The frequency of genotype and allele of rs7903146 polymorphism in Amish population also reported a similar results $(p=0.008)$ by Damcot et al. (2006).

The polymorphism is affected by geographical and ethnical differences, so it causes genotype frequency differences. The TCF7L2 gene genotype frequencies showed variations geographically and ethnically. The population of French, Dutch, Afro-American, and Mexico have a high TCF7L2 gene rs7903146 genotype frequency (Goodarzi et al., 2007; Bodhini et al., 2007; Moczulski et al., 2007).

In this study, the genotype distribution of the rs7903146 polymorphism of TCF7L2 gene was not diverge from Hardy-Weinberg equilibrium $(p=1.000)$. It can be concluded that genotype and allele frequencies at 
this population were distributed normally. Individual with type $2 \mathrm{DM}$ family history have a low frequency of T allele and CT/TT genotypes. The same results were reported at Arabian population (Alsmadi et al., 2008) and Indian Pima population (Guo et al., 2007) that rs7903146 has low risk to type 2 $\mathrm{DM}(\mathrm{OR}=1.04)$. In another study conducted in France population (Moczulski et al., 2007) and Italian population (Gambino et al., 2010) were reported different result that rs7903146 was a risk factor of type $2 \mathrm{DM}$.

The mean of insulin levels was lower among subjects with type 2 DM family history than subjects without type $2 \mathrm{DM}$ family history $(p=0.00)$. Chen et al. (2012) and Arslanian et al. (2005) also found that insulin level of subject with type $2 \mathrm{DM}$ family history was lower than subjects without type 2 DM family history. The low insulin level on subjects with type 2 DM family history indicates that there was a decreasing insulin secretion due to abnormality of pancreatic $\beta$-cell (Arslanian et al., 2005).

HOMA- $\beta$ was employed for evaluation of pancreatic $\beta$-cell (Chen et al., 2012). HOMA- $\beta$ values were parallel with the results of insulin levels, which is significantly lower in subjects with a type 2 DM family history than in subjects without a type $2 \mathrm{DM}$ family history. Chen et al. (2012) was shown that individuals with type 2 DM family history has impaired function of pancreatic $\beta$-cell with low HOMA- $\beta$ level compared with HOMA- $\beta$ level of subjects without type 2 DM family history. The decreasing of insulin secretion resulted from impaired function of pancreatic $\beta$-cell which caused by several factor, include genetic factors (DeFronzo et al., 2008).

In this study, the number of samples that have been enrolled is much lower than in the other study. Insufficient number of samples caused TT genotype could not be found in this study. Certainly, a limitation of this study.

\section{Conclusion}

The polymorphism of TCF7L2 gene is not risk of individuals with and without type 2 DM family history in Indonesian population. The Insulin secretion on individuals with type 2 DM family history was lower than that of individuals without type $2 \mathrm{DM}$ family history.

\section{Acknowledgment}

This study was supported by grant from Indonesian Directorate General of Higher Education (DGHE), Ministry of education and culture.

\section{Reference}

Alibegovic, A., C, Sonne, M., P, Hojbjerre, L, Hansen, T, Pedersen, O, Hall, G., et al., 2010. The T-Allele Of TCF7L2 rs7903146 Associates With a Reduced Compensation Of Insulin Secretion For Insulin Resistance Induced by 9 Days Of Bed Rest. ADA. 59: 836-843.

Alsmadi, O., Al-Rubean, K., Mohamed, G., Alkayal, F., Al-Saud, H., Al-Saud, N. A., et al. 2008. Weak or no association of TCF7L2 variants with type 2 diabetes risk in an arab population. BMC Med Genet.72-79.

Anuurad, E., Shiwaku, K., Nogi, A., Kitajima, K., Enkhmaa, B., Shimono, K., et al., 2003. The new BMI criteria for Asians by the regional office for the western pacific region of $\mathrm{WHO}$ are suitable for screening of overweight to prevent metabolic syndrome in elder Japanese workers. J Occup Health. 45: 335-343.

Arslanian, A. S., Bacha, F., Saad, R., Gungor, N., 2005. Family History of type 2 diabetes is associated with decreased insulin sensitivity and an impaired balance between insulin sensitivity and insulin secretion in white youth. Diabetes Care.127-131.

Bener, A., Yousafzai, M. T., Al-Hamaq, A., Mohammad, A., and Defronzo, R., 
2013.Parental transmission of type 2 diabetes mellitus in a highly endogamous population.World J Diabetes. 4(2): 40-46.

Bodhini, D., Radha, V., Dhar, M., Narayani, N., Mohan, V., 2007. The rs12255372 (G/T) and rs7903146 (C/T) polymorphisms of the TCF7L2 gene are associated with type 2 diabetes mellitus in Asian Indians. Met Clin Exp. 1174-1178.

Chen, G., Li, M., Xu, Y., Chen, N., Huang, H., Liang, J., et al., 2012. Impact of Family History of Diabetes on $\beta$-Cell Function and Insulin Resistance Among Chinese with Normal Glucose Tolerance. Diabetes Tech ETherap. Vol.14, No.6. 463-468.

Damcott, C. M., Pollin, T. I., Reinhart, L. J., Ott, S. H., Shen, H., Silver, K. D., et al., 2006. Polymorphisms in the Transcription Factor 7-like 2 (TCF7L2) Gene Are Associated With Type 2 Diabetes in the Amish. Diabetes. 55: 2654-2659.

Danadian, K., Balasekaran, G., Lewy, V., Meza, M. P., Robertson, R., Arslanian, S. A., 1999. Insulin sensitivity in AfricanAmerican children with and without family history of type 2 diabetes. Diabetes Care. 22: 1325-1329.

Das, M., Pal, S., Ghost, A., 2012. Family history of type 2 diabetes and prevalence of metabolic syndrome in adult asianindians. J Cardiovasc Dis. 3: 104-108.

DeFronzo, R., 2008. Banting Lecture presentated atThe Annual Meeting of ADA San Fransisco.

Erasmus, R. T., Blanco, E. B., Okesina, A. B., Arana, J. M., Ggweta, Z., Matsha, T., 2001. Importance of family history in type 2 black South African diabetics. Postrad Med J. 77:323-325.

Gambino, R., Bo, S., Gentile, L., Pagano, G., Perin, C. P., Cassader, M., 2010. Transcription factor 7 like-2 (TCF7L2) polymorphism and hyperglycemia in an adult italian population-based cohort. Diabetes Care.1233-1235.

Gaulton, J. K., Nammo, T., Pasquali, L., Simon, M. J., Giresi, G. P., Fogarty, P.
M., et al., 2010.A map of open chromatin in human pancreatic islets.Nat Genet. 42: 255-259.

Goodarzi, M. O., and Rotter, J. I., 2007. Testing the gene or testing a variant? The case of TCF7L2.Diabetes. 56:2417-2419.

Guo, T., Hanson, L. R., Traurig, M., Muller, L. Y., Ma, L., et al., 2007. TCF7L2 is not a major susceptibility gene for type 2 diabetes in Pima Indians. Diabetes. 56: 3082-3088.

Harrison, T. A., Hindorff, L. A., Kim, H., Wines, R. C., Bowen, D. J., McGrath, et al., 2003. Family history of diabetes as a potential public health tool.Am J Prev Med.24: 152-159.

Jyothi, U. K., Jayaraj, M., Subburaj, S. K., Prasad, J. K., Kumuda, I., Lakhsmi, V., et al., 2013.Association of TCF7L2 gene polymorphisms with T2DM in the population of Hyderabad, India. Plos One. 8. e60612.

Lyssenko, V., Lupi, R., Marchetti, P., Guerra, S. D., Melander, M., Almgren, P., et al., 2007. Mechanisms By Which Common Variants In The TCF7L2 Gene Increase Risk Of Type 2 Diabetes. J Clin Invest. 117:2155-2163.

Marquezine, G. F., Pereira, A. C., Sousa, A. G. P., Mill, J. G., Hueb, W. A., Krieger, J. E., 2008. TCF7L2 variant genotypes and type 2 diabetes risk in Brazil : significant association, but not a significant tool for risk stratification in the general population. BMC Med Genet.9: 106.

Miyake, K., Horikawa, Y., Hara, K., Yasuda, K., Osawa, H., Furuta, H., et al. 2007. Association Of TCF7L2 Polymorphisms With Susceptibility To Type 2 Diabetes in 4087 Japanese Subjects. J Hum Genet. 53:174-180.

Moczulski, D., Gawlik, B., August, R., Strojek, K., and Grzeszak, W., 2007. TCF7L2 Gene is Associated With Type 2 Diabetes in Polish Population. DDK. Vol.7: 2. 109-111.

Oya, J., Nakagami, T., Yamamoto, Y., Fukushima, S., Takeda, M., Endo, Y., 
Uchigata, Y., 2014. Effets of Age on Insulin Resistance and Secretion in Subjects without Diabetes. Intern Med. 53: 941-947.

PERKENI, (2011) Konsensus Pengendalian dan Pencegahan Diabetes Melitus Tipe 2 di Indonesia.

Shu, L., Sauter, N. S., Schulthess, F. T., Matveyenko, A. V., Oberholzer, J., Maedler, K., 2008. Transcription Factor 7-like 2 Regulates $\beta$-cell Survival and Function in Human Pancreatic Islets. Diabetes. 57:645-653.

Shu, L., Matveyenko, V. A., Kerr, J., Cho, J., Mclntosh, H. S. C., Maedler, K., 2009. Decreased TCF7L2 protein levels in type 2 diabetes mellitus correlate with downregulation of GIP- and GLP-1 receptors and impaired beta-cell function. Hum Mol Gen. 2388-2399.

Tong, Y., Lin, Y., Zhang, Y., Yang, J., Zhang, Y., Liu, H., et al., 2009. Association between TCF7L2 gene polymorphisms and susceptibility to Type 2 Diabetes Mellitus : a large Human Genome Epidemiology (HuGE) review and meta-analysis. BMC Med Gen. 10:15.

Vliet, J. V., Shiri, R., Zhernakova, A., Strengman, E., Haeften, T. W., Hofker, M. H., et al., 2006. Association of Variants of Transcription Factor 7-like 2 (TCF7L2) With Susceptibility to Type 2 Diabetes in The Dutch Breda Cohort. Diabetologia. 50: 59-62.

Wang, J., Kuusisto, J., Vanttinen, M., Kuulasmaa, T., Lindstrom, J., Tuomilehto, J., et al., 2007. Variants of transcription factor 7-like 2 (TCF7L2) gene predict conversion to type 2 diabetes in the Finnish Diabetes Prevention Study and are associated with impaired glucose regulation and impaired insulin secretion. Diabetologia. 50: 1192-1200.

Wegner, L., Hussain, M. S., Pilgaard, K., Hansen, T., Pedersen, O., Vaag, A., et al., 2008. Impact of TCF7L2 rs7903146 on Insulin Secretion and Action in Young and Elderly Danish Twins.Endo Meta. 93:4013-4019.

Wicaksono, R. P., (2011). Faktor-Faktor yang Berhubungan Dengan Kejadian Diabetes Melitus Tipe 2. Universitas Diponegoro Semarang. 16 - 17.

Xavier, G. S., Loder, M. M., McDonald, Angela., Tarasov, A. I., Carzaniga, R., et al., 2009. TCF7L2 Regulates Late Events in Insulin Secretion From Pancreatic Islet $\beta$-Cells. Diabetes. 58:894-905.

Yu, J., Steck, A. K., Babu, S., Yu, L., Miao, D., McFann, K., et al., 2009. Single Nucleotide Transcription Factor 7-Like 2 (TCF7L2) Gene Polymorphisms in Anti islet Autoantibody-Negative Patients at Onset of Diabetes. Endocrine Care. 94(2):504-510. 
